\title{
Circadian changes in the composition of human milk macronutrients depending on pregnancy duration: a cross-sectional study
}

\author{
leva Jura Paulaviciene ${ }^{1,2^{*}}$ D, Arunas Liubsys ${ }^{1,2}$, Alma Molyte $^{3,4}$, Audrone Eidukaite ${ }^{2,5}$ and Vytautas Usonis ${ }^{1,2}$
}

\begin{abstract}
Background: The purpose of this study was to evaluate the circadian variation of human milk macronutrients and energy content depending upon pregnancy duration.

Methods: One hundred eighty fresh human milk samples from 45 mothers (27 of preterm and 18 of full-term newborns) were collected on a single day chosen between the 14th to 16th day after delivery. The samples were taken four times per day at 12 PM, 6 PM, 12 AM and 6 AM. Only lactating women, who could not breastfeed their hospitalized newborns and expressed milk by breast pump, were enrolled in the study. Human milk macronutrient composition and energy count were evaluated by mid-infrared spectrophotometry.

Results: Significant differences in macronutrient content were observed between 6 AM and 12 PM for mean protein content $(t=-4.62, d f=44, p<0.001)$, for mean fat content $(t=-2.10, d f=44, p=0.04)$ and for mean energy content $(t=-2.24, d f=44, p=0.03)$; between $6 \mathrm{AM}$ and $6 \mathrm{PM}$ for mean protein content $(t=-2.41, d f=43$, $p=0.02)$, for mean fat content $(t=-3.76, d f=43, p=0.001)$ and for mean energy content $(t=-3.85, d f=43$, $p<0.001$ ); between $12 \mathrm{PM}$ and $12 \mathrm{AM}$ for mean protein content (Wilcoxon test $\mathrm{V}=75.5, p=0.001$ ), for mean fat content ( $t=2.50, d f=44, p=0.02)$ and for mean energy content $(t=2.74, d f=44, p=0.01)$; between 6 PM and 12 AM for mean protein content $(V=229, p=0.02)$, for mean fat content $(t=4.39, d f=43, p<0.001)$ and for mean energy content $(t=-4.57, d f=43, p<0.001)$. The average content of carbohydrates did not change significantly during the $24 \mathrm{~h}$. The samples of preterm newborns' mothers had more apparent diurnal fluctuations in macronutrient content.
\end{abstract}

Conclusions: Our study revealed significant diurnal variations in protein and fat in human milk, and these circadian fluctuations were more apparent in the milk of mothers of preterm infants.

Keywords: Circadian variation, Human milk, Macronutrient, Mid-infrared spectrophotometry

\footnotetext{
* Correspondence: ieva.paulaviciene@mf.vu.lt

${ }^{1}$ Clinic of Children Diseases, Institute of Clinical Medicine, Faculty of

Medicine, Vilnius University, Vilnius, Lithuania

${ }^{2}$ Vilnius University Hospital Santaros Klinikos, Vilnius, Lithuania

Full list of author information is available at the end of the article
}

(c) The Author(s). 2020 Open Access This article is licensed under a Creative Commons Attribution 4.0 International License, which permits use, sharing, adaptation, distribution and reproduction in any medium or format, as long as you give appropriate credit to the original author(s) and the source, provide a link to the Creative Commons licence, and indicate if changes were made. The images or other third party material in this article are included in the article's Creative Commons licence, unless indicated otherwise in a credit line to the material. If material is not included in the article's Creative Commons licence and your intended use is not permitted by statutory regulation or exceeds the permitted use, you will need to obtain permission directly from the copyright holder. To view a copy of this licence, visit http://creativecommons.org/licenses/by/4.0/. The Creative Commons Public Domain Dedication waiver (http://creativecommons.org/publicdomain/zero/1.0/) applies to the data made available in this article, unless otherwise stated in a credit line to the data. 


\section{Background}

Human milk is a dynamic biological liquid whose composition varies in response to many factors, matching individual infant requirements. It is likely that changes in human milk composition are essential for health and growth, as well as for the development of infants. Each woman's milk composition is unique. Factors that can influence human milk composition may be maternal (e.g., metabolic health, diet, and obstetric history), infant (e.g., gender, gestational age, and birth weight), physiological (e.g., stage of lactation, circadian rhythm, and stage of nursing), behavioural (e.g., time between feedings and manual or breast pump expression), and methodological (e.g., choice of analytical procedures, freeze-defrost cycles) [1-4].

Human milk macronutrient composition has been well analysed in correlation with increasing lactation time [2, 5-7], while less is known about its circadian changes. According to the available knowledge, diurnal changes mostly affect lipids [8-11], while data regarding other macronutrients remain conflicting. Although there are discrepancies in the composition of milk during different lactation periods between the mothers of preterm and term infants $[2,5]$, there is still a paucity of knowledge about the circadian differences in milk composition between these two groups. Additionally, it is not clear whether the circadian variation of human milk macronutrient content has potential benefits for infants' health and well-being [12].

Since human milk composition strongly depends on the type of samples collected [1, 4, 13], the milk sampling procedure should be performed under standardised conditions, with the corresponding method chosen according to the purpose of the analysis. It has been shown that the mean concentration of total fat in milk obtained by an electric pump is higher than that of handexpressed milk [4]. Electric pump use is recommended for the regular expression of milk, and the handoperated pump could be the second choice. Hand expression is not recommended, and drip milk is not suitable for obtaining representative milk samples [14]. The macronutrient content varies depending on the degree of breast fullness; therefore, the breast should be entirely emptied, and milk should be mixed before analysis to obtain reliable results $[1,13,15]$.

The purpose of our study was to test the circadian changes in human milk macronutrients and energy content among women who delivered their newborns at different gestational ages by mid-infrared spectrophotometry using a Miris Human Milk Analyser.

\section{Methods}

The cross-sectional study was conducted from October 2017 to May 2018 at the Neonatal Center of Vilnius
University Hospital Santaros Klinikos. It is one of two perinatal centres in Lithuania where the majority of very low and extremely low birth weight newborns are concentrated from all over the country. The study was approved by the local bioethics committee (permission No. 158200-17-925-443). Before being enrolled in the study, all participating women provided written informed consent.

Women were eligible to participate in the study if they were healthy (no history of diabetes, hepatitis B or C, HIV, tuberculosis, mastitis, or oncological diseases), had a single-birth pregnancy and were not on a special diet. Only lactating mothers who could not breastfeed their newborns due to the baby's medical condition (either prematurity or disease) but who expressed milk that could be used for the feeding of their own babies were enrolled in the study. Breastfeeding mothers were excluded from the study for ethical reasons (for minimising nutritional or behavioural disruption to the mother and the newborn) and to avoid the influence of previous breastfeedings on the human milk macronutrient content during milk collection for analysis.

Verbal instructions for milk sample collection and appropriate use of milk pumps were given to the women at the beginning of the enrolment in the study. Milk samples from 45 mothers (27 of preterm and 18 of fullterm newborns) were collected on a single day chosen between the 14th and 16th day after delivery. The samples were taken four times during the chosen day at the collection points of 12 PM, 6 PM 12 AM and 6 AM $( \pm 1$ h). This lactation period was chosen for milk analysis due to the stability of maternal milk production and the ability of the mothers to have sufficient milk to donate some for analysis. Expressing milk every $3 \mathrm{~h}$ before feeding the babies is a common practice among mothers at our neonatal centre; therefore, the particular hours for milk sampling were chosen to not disrupt their daily milk expression routine. A timeline summarising the timing of milk expression for feeding versus samples for analysis over the course of the day is presented in Fig. 1.

After one or both breasts were fully emptied with an electrical or manual breast pump and the milk was carefully mixed in the container, samples of $10 \mathrm{~mL}$ milk were immediately collected in separate sterile plastic containers. The remaining amount of the expressed fresh milk was used to feed the newborns. After being labelled (ID number, data and correct time of collection), each sample was stored in a refrigerator at $+4{ }^{\circ} \mathrm{C}$ for further analysis of the milk's macronutrient composition. The majority of the milk samples (44 out of 46 participating women) were analysed 22 to $25 \mathrm{~h}$ after the beginning of the collection (at $12 \mathrm{PM}$ ), while the samples of two mothers were collected during the weekend and stored 


\section{Timing of milk sampling for analysis}

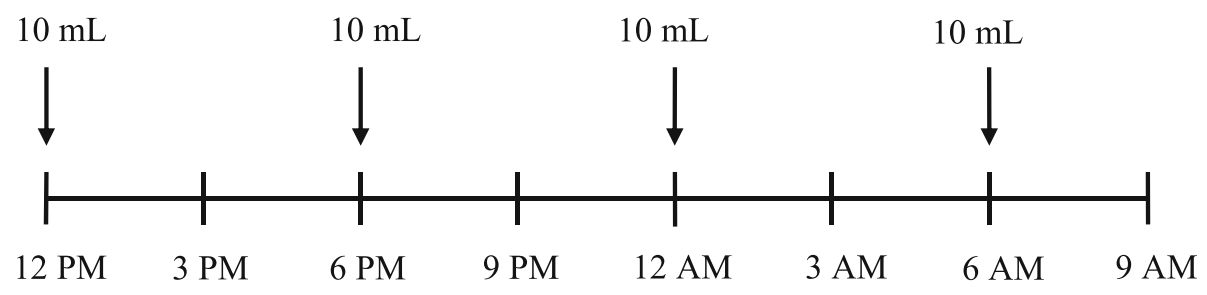

\section{Timing of milk expression for feeding}

Fig. 1 Timing of milk expression and sample collection

in the refrigerator up to $48 \mathrm{~h}$ before being analysed (due to the day off of the milk bank).

The milk's macronutrient and energy content was evaluated by mid-infrared spectrophotometry using the Miris Human Milk Analyser (Miris AB, Sweden), which was operated using the calibration mode for processed (homogenised) milk. According to the manufacturer's instructions, prior to analysis, the milk samples were warmed to $40^{\circ} \mathrm{C}$ and homogenised for $1.5 \mathrm{~s} / \mathrm{mL}$ using the Miris Ultrasonic Processor. A daily calibration check was performed using the calibration solution (MIRIS check), which was provided by the supplier.

Statistical analysis was performed using the $\mathrm{R}$ program version 3.4.4. Data were summarized as the mean \pm standard deviation. The Chi-square and exact Fisher test were used to establish significant differences between the groups. The Shapiro-Francia test was used to determine the normality of the data. In order to compare the two groups, we used the Student t test when the data were normally distributed. In other cases, we used the Wilcoxon test to compare non-parametric groups. Cohen's d effect size for $t$ test was calculated. Cohen's d values between $\geq 0.2$ and $<0.5$ indicate small-size effect, values between $\geq 0.5$ and $<0.8$ indicate medium-size effect, and values $\geq 0.8$ indicate large-size effect [16]. Statistical significance was achieved when the $p$ value was $<0.05$.

\section{Results}

A total of 180 samples from 45 lactating mothers were collected and analysed for macronutrient and energy content. All participating women were permanent residents of Lithuania. The main characteristics of the women enrolled in the study are presented in Table 1. The mothers of term and preterm newborns were similar regarding newborn gender, delivery mode, age, ethnicity and number of deliveries.

Analysis of all 180 samples from the 45 women enrolled in the study showed significant diurnal variation of protein, fat, and energy content, with the highest levels of these macronutrients and energy content during day expressions (at $12 \mathrm{PM}$ and $6 \mathrm{PM}$ ) and with the lowest during night expressions (at $12 \mathrm{AM}$ and $6 \mathrm{AM}$ ). The

Table 1 Characteristics of the mothers of preterm and term newborns

\begin{tabular}{|c|c|c|c|c|c|}
\hline Characteristics & $\begin{array}{l}\text { Term (GA } \geq 37 \text { weeks), } \\
n=18\end{array}$ & Preterm (GA $<37$ weeks), $n=27$ & $t$ & $d f$ & $p$ value \\
\hline $\begin{array}{l}\text { Gestational age (weeks), } \bar{x} \pm s \\
\text { Range (weeks) }\end{array}$ & $\begin{array}{l}38.7 \pm 1.0 \\
37-40\end{array}$ & $\begin{array}{l}30.2 \pm 2.5 \\
24-36\end{array}$ & -15.61 & 37.04 & $<0.001$ \\
\hline $\begin{array}{l}\text { Birth weight }(\mathrm{g}), \bar{x} \pm s \\
\text { Range }(\mathrm{g})\end{array}$ & $\begin{array}{l}3265 \pm 589 \\
1590-3960\end{array}$ & $\begin{array}{l}1477 \pm 405 \\
845-2380\end{array}$ & -12.09 & 43 & $<0.001$ \\
\hline Gender (male / female), n (\%) & $11 / 7(61.1 / 38.9)$ & 18/9 (66.7/33.3) & 0.15 & 1 & 0.703 \\
\hline Delivery mode (VD / CS), n (\%) & $15 / 3(83.3 / 16.7)$ & $16 / 11(59.3 / 40.7)$ & 2.92 & 1 & 0.087 \\
\hline $\begin{array}{l}\text { Number of deliveries, } \bar{x} \pm s \\
\text { Range, } \mathrm{n}\end{array}$ & $\begin{array}{l}1.6 \pm 0.7 \\
1-3\end{array}$ & $\begin{array}{l}1.7 \pm 0.9 \\
1-5\end{array}$ & 0.22 & 43 & 0.829 \\
\hline $\begin{array}{l}\text { Maternal age }(y), \bar{x} \pm s \\
\text { Range }(y)\end{array}$ & $\begin{array}{l}30.9 \pm 6.2 \\
19-40\end{array}$ & $\begin{array}{l}32.9 \pm 4.3 \\
24-43\end{array}$ & 1.28 & 43 & 0.209 \\
\hline Ethnicity (Lithuanian, other ${ }^{\mathrm{a}}$ ), n (\%) & $14 / 4(77.8 / 22.2)$ & 23/4 (85.2/14.8) & 0.25 & 1 & 0.694 \\
\hline
\end{tabular}

$\bar{x} \pm s$ mean value \pm standard deviation, VD vaginal delivery, CS caesarean section, GA gestational age; $t$ test value, $d f$ degrees of freedom

a other ethnicities: Russians, Poles, Ukrainians 
Table 2 Macronutrient and energy content in preterm and term human milk $(n=45)$ during the daytime

\begin{tabular}{|c|c|c|c|c|c|c|c|}
\hline & & \multicolumn{6}{|c|}{ Time of day (hours) } \\
\hline & & $6 A M-12 P M$ & $6 A M-6 P M$ & $6 \mathrm{AM}-12 \mathrm{AM}$ & $12 P M-6 P M$ & $12 \mathrm{PM}-12 \mathrm{AM}$ & $6 P M-12 A M$ \\
\hline \multirow[t]{3}{*}{ Protein, g/100 mL } & $\bar{x} \pm s$ & $\begin{array}{l}1.37 \pm 0.2 \\
1.43 \pm 0.2\end{array}$ & $\begin{array}{l}1.37 \pm 0.2 \\
1.41 \pm 0.2\end{array}$ & $\begin{array}{l}1.37 \pm 0.2 \\
1.37 \pm 0.2\end{array}$ & $\begin{array}{l}1.43 \pm 0.2 \\
1.41 \pm 0.2\end{array}$ & $\begin{array}{l}1.43 \pm 0.2 \\
1.37 \pm 0.2\end{array}$ & $\begin{array}{l}1.41 \pm 0.2 \\
1.37 \pm 0.2\end{array}$ \\
\hline & $p$ value & $<0.001^{* *}$ & $0.02^{*}$ & 0.90 & 0.24 & $0.001^{*}$ & $0.02^{*}$ \\
\hline & Cohen's d & $0.30^{\mathrm{a}}$ & $0.20^{\mathrm{a}}$ & 0 & 0.10 & $0.30^{\mathrm{a}}$ & $0.20^{\mathrm{a}}$ \\
\hline \multirow[t]{3}{*}{ Fat, g/100 mL } & $\bar{x} \pm s$ & $\begin{array}{l}4.06 \pm 0.9 \\
4.39 \pm 1.1\end{array}$ & $\begin{array}{l}4.06 \pm 0.9 \\
4.57 \pm 1\end{array}$ & $\begin{array}{l}4.06 \pm 0.9 \\
4.00 \pm 0.7\end{array}$ & $\begin{array}{l}4.39 \pm 1.1 \\
4.57 \pm 1.0\end{array}$ & $\begin{array}{l}4.39 \pm 1.1 \\
4.00 \pm 0.7\end{array}$ & $\begin{array}{l}4.57 \pm 1.0 \\
4.00 \pm 0.7\end{array}$ \\
\hline & $p$ value & $0.04^{*}$ & $0.001^{*}$ & 0.65 & 0.28 & $0.02^{*}$ & $<0.001^{* *}$ \\
\hline & Cohen's d & $0.33^{\mathrm{a}}$ & $0.50^{\mathrm{b}}$ & 0.07 & 0.17 & $0.42^{\mathrm{a}}$ & $0.66^{\mathrm{b}}$ \\
\hline \multirow[t]{3}{*}{ Carbohydrate, g/100 mL } & $\bar{x} \pm s$ & $\begin{array}{l}7.39 \pm 0.2 \\
7.33 \pm 0.3\end{array}$ & $\begin{array}{l}7.39 \pm 0.2 \\
7.33 \pm 0.2\end{array}$ & $\begin{array}{l}7.39 \pm 0.2 \\
7.37 \pm 0.2\end{array}$ & $\begin{array}{l}7.33 \pm 0.3 \\
7.33 \pm 0.2\end{array}$ & $\begin{array}{l}7.33 \pm 0.3 \\
7.37 \pm 0.2\end{array}$ & $\begin{array}{l}7.33 \pm 0.2 \\
7.37 \pm 0.2\end{array}$ \\
\hline & $p$ value & 0.12 & 0.14 & 0.40 & 0.88 & 0.27 & 0.22 \\
\hline & Cohen's d & $0.24^{\mathrm{a}}$ & $0.24^{\mathrm{a}}$ & 0.08 & 0 & 0.16 & $0.20^{\mathrm{a}}$ \\
\hline \multirow[t]{3}{*}{ Energy, kcal/ 100 mL } & $\bar{x} \pm s$ & $\begin{array}{l}74.42 \pm 9.1 \\
77.58 \pm 10.0\end{array}$ & $\begin{array}{l}74.42 \pm 9.1 \\
79.18 \pm 9.7\end{array}$ & $\begin{array}{l}74.42 \pm 9.1 \\
73.89 \pm 6.8\end{array}$ & $\begin{array}{l}77.58 \pm 10.0 \\
79.18 \pm 9.7\end{array}$ & $\begin{array}{l}77.58 \pm 10.0 \\
73.89 \pm 6.8\end{array}$ & $\begin{array}{l}79.18 \pm 9.7 \\
73.89 \pm 6.8\end{array}$ \\
\hline & $p$ value & $0.03^{*}$ & $<0.001^{* *}$ & 0.59 & 0.29 & $0.01^{*}$ & $<0.001^{* *}$ \\
\hline & Cohen's d & $0.33^{\mathrm{a}}$ & $0.51^{b}$ & 0.07 & 0.16 & $0.43^{\mathrm{a}}$ & $0.63^{b}$ \\
\hline
\end{tabular}

$\bar{x} \pm s$ mean value \pm standard deviation; Cohen's $d-$ Cohen's d effect size

a - small effect size, ${ }^{b}$ medium effect size; significant differences are highlighted in bold $\left({ }^{*} p<0.05 ;{ }^{* *} p<0.001\right)$

carbohydrate content in the human milk did not reveal significant diurnal fluctuations (Table 2).

A comparison of macronutrient content changes in preterm and term human milk separately during the time of the day is presented in Fig. 2. Macronutrients and energy content did not differ significantly when comparing the preterm and term human milk samples, but the diurnal variations were more pronounced in the preterm milk samples.

Although protein content revealed similar diurnal fluctuations in both the preterm and full-term milk samples, with the highest levels during day expressions (at 12 PM and $6 \mathrm{PM}$ ), these differences were not significant. The preterm milk samples also contained more protein than

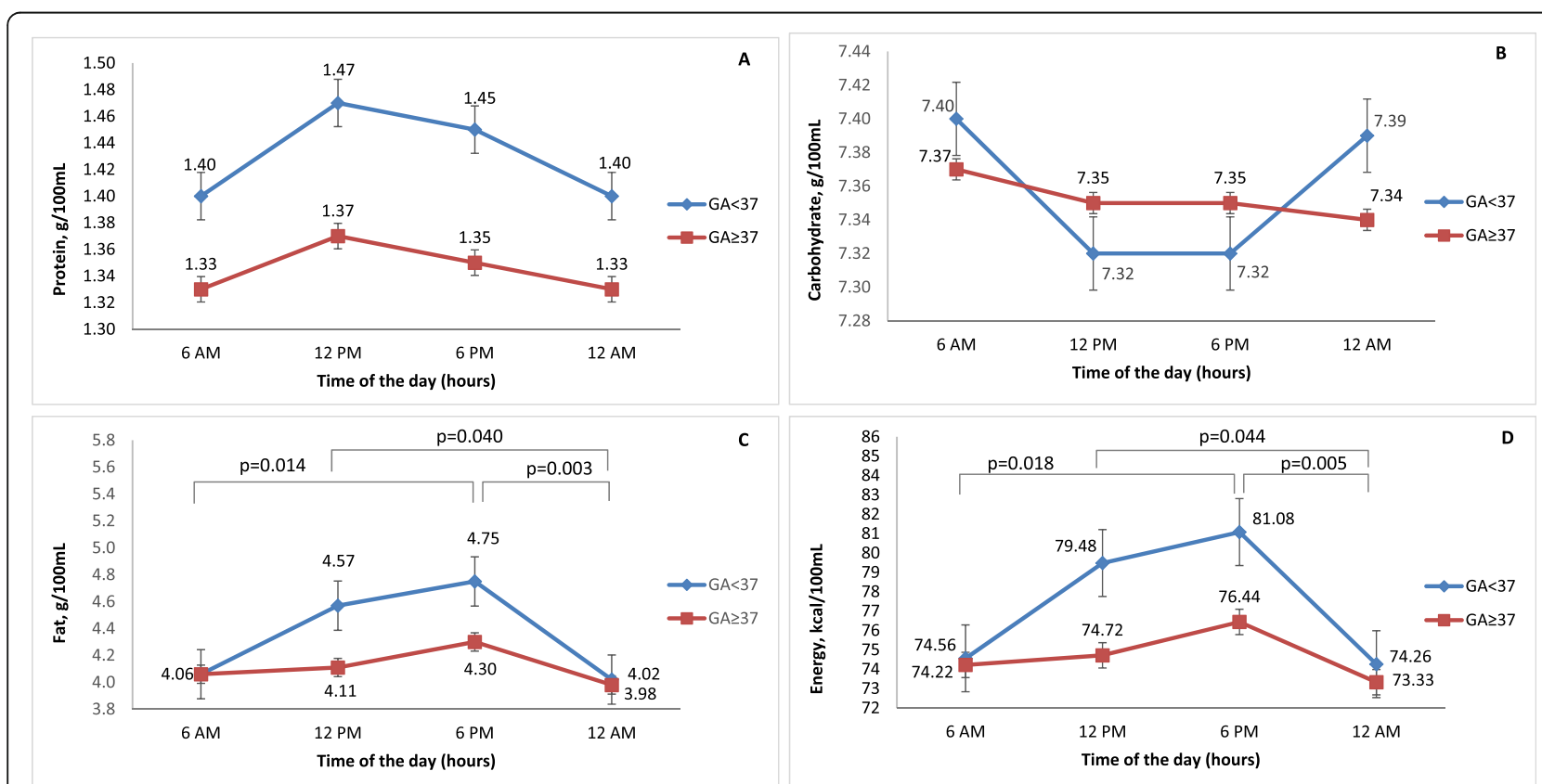

Fig. 2 Comparison of macronutrient content in preterm $(n=18)$ and term $(n=27)$ human milk by time of day; GA - gestational age (weeks). Significant differences in fat and energy content were found only in the preterm group $(G A<37)$ 
the full-term samples, but the differences were not significant (Fig. 2a).

Carbohydrate content did not show apparent diurnal fluctuations in the full-term samples but showed more apparent diurnal fluctuations in the preterm milk samples, although these differences did not reach significance. In contrast to the case for proteins, the highest concentration of carbohydrates in preterm milk was observed during night expression, and the lowest was observed during the day (Fig. 2b).

We found significant differences in the diurnal fluctuations of fat and energy, with peak concentrations at 12 PM and 6 PM in the preterm milk samples, but these differences did not reach significance in the full-term milk samples (Fig. 2c and d).

\section{Discussion}

Our study is the first to investigate circadian changes in human milk macronutrients in Lithuania. Circadian changes in human milk composition have already been analysed in a number of studies, but the presented results are very heterogeneous due to the different designs, number of subjects, and methods used for milk analysis. The previous studies found in PubMed are summarised in Table 3.

There is yet no clear explanation but only suggestions and speculations of why these diurnal fluctuations of human milk composition exist and what impact they have on a newborn's health and development. Hormonal changes in lactating women, breastfeeding patterns, the influence of the degree of breast fullness, circadian dietary habits, ethnic differences, and different techniques for the measurement of milk macronutrients are among the factors that can influence circadian changes in milk composition $[9,27,29,30]$. However, the particular role of each factor and why and how these factors affect dynamic changes in specific macronutrients are unknown.

A number of methods for human milk macronutrient analysis have been used over the decades. Mid-infrared spectroscopy was the method of choice for human milk composition analysis in our study, as well as in a number of other studies $[11,27,28]$. There are some discrepancies, but there is also reliability comparing values of human milk macronutrients using mid-infrared spectroscopy and biochemical methods [31-34]. The main task of our study was to evaluate the dynamic changes in but not the absolute values of the macronutrient content of the human milk of mothers of preterm and full-term newborns during a 24-h period.

While most of the studies (as well as our study) show that the greatest circadian variation is in the fat content in human milk [9-11, 17, 21, 24], the data regarding other macronutrients remain controversial.
The DARLING study [29] showed that the macronutrient content in human milk could be influenced by breast fullness; human milk protein and fat concentrations were negatively related to milk volume, while milk lactose concentration was positively related to milk volume at certain lactation periods. In our study, the majority of the women usually rested at night and did not empty their breasts early in the morning ( $3 \mathrm{AM})$, so their breasts were full for the morning sampling (6 AM) compared to the midnight sampling. In spite of this, we did not find any differences in fat and protein content in the midnight and morning samples, different from other researchers.

The results regarding circadian fluctuations in protein content are still conflicting. Sánchez López and colleagues [25] found circadian changes in protein content during the mature milk stage with the highest protein concentrations during night (8 PM-8 AM) expression. In contrast to the Spanish study, we found the highest levels of protein during day expression (at $12 \mathrm{PM}$ and 6 $\mathrm{PM}$ ) and the lowest levels during night expression (at 6 $\mathrm{AM}$ and $12 \mathrm{AM})$. Keeping in mind that diurnal variations of the fat content of expressed milk had the same trend, we could only relate these fluctuations to the dietary habits of hospitalised women, i.e., day samples (at 12 PM and 6 PM) of milk were taken after breakfast and lunch meals, while night samples (at $12 \mathrm{AM}$ and $6 \mathrm{AM}$ ) were taken on an empty stomach - relative to after a fasting period. Other investigators did not find any circadian changes in protein or nitrogen substance content, but the number of women participating in the studies was relatively small $[11,19,20,24,26]$. When analysing the preterm and full-term milk samples separately, we did not find significant differences in the circadian fluctuations of protein content in the two groups, although the preterm milk samples tended to show more apparent circadian variations of protein concentration than the full-term samples. We anticipate that the differences did not reach significance because of the small sample size of the preterm milk samples, despite the clear tendency of circadian variations.

Human milk carbohydrates showed the least variation in macronutrient concentrations over $24 \mathrm{~h}$. Our results agree with those of previous studies showing no circadian variation in carbohydrate concentrations $[11,26$, 27]. On the other hand, in our study, the preterm milk samples also tended to show more apparent circadian variations in carbohydrate content than the full-term samples.

We, like many other investigators, cannot find a reasonable explanation for the circadian changes of macronutrients in human milk but can only speculate with regard to the possible influence of the ethnicity or dietary habits of the mothers. It also seems that prematurity 
Table 3 Summary of the studies on circadian changes in human milk macronutrient content

\begin{tabular}{|c|c|c|c|c|c|c|}
\hline Reference & Site & $\begin{array}{l}\text { Participants } \\
\text { (number) }\end{array}$ & $\begin{array}{l}\text { Lactation } \\
\text { stage }\end{array}$ & $\begin{array}{l}\text { Macronutrients } \\
\text { investigated }\end{array}$ & Analytical methods & Results \\
\hline $\begin{array}{l}\text { Gunther M } \\
\text { et al., } 1949 \\
\text { [8] }\end{array}$ & Germany & 8 & $\begin{array}{l}8-11 \text { days of } \\
\text { lactation }\end{array}$ & Fat & Gerber & $\begin{array}{l}\text { The highest concentrations in the } \\
\text { morning and at noon and the } \\
\text { lowest between } 8 \text { PM and } 4 \text { AM }\end{array}$ \\
\hline $\begin{array}{l}\text { Prentice A } \\
\text { et al., } 1981 \\
{[17]}\end{array}$ & Gambia & 60 & $\begin{array}{l}1-18 \text { months } \\
\text { after delivery }\end{array}$ & Fat & CMT & $\begin{array}{l}\text { A marked diurnal variation (the } \\
\text { highest values in the early } \\
\text { morning, the lowest in the late } \\
\text { afternoon) }\end{array}$ \\
\hline $\begin{array}{l}\text { Harzer G } \\
\text { et al., } 1983 \\
{[18]}\end{array}$ & Germany & $\begin{array}{l}17 \text { (13 German } \\
\text { and } 4 \text { English) }\end{array}$ & $\begin{array}{l}\text { First } 5 \text { weeks } \\
\text { of lactation }\end{array}$ & Lipid & Thin-layer chromatography & $\begin{array}{l}\text { Milk samples from German } \\
\text { mothers had their peak lipid } \\
\text { content in the afternoon (noon to } \\
6 \text { PM), while the English samples } \\
\text { had their respective peaks in the } \\
\text { evening (6 PM to midnight) }\end{array}$ \\
\hline
\end{tabular}

et al., $1986 \quad$ term infants) lactation modified Folch procedure (lipid)

[19]

Clark RM

$1987[20]$

US

7 (mothers of

8th week of term infants) lactation

\begin{tabular}{|c|c|}
\hline $\begin{array}{l}\text { Jackson } \\
\text { DA et al., } \\
1988 \text { [21] }\end{array}$ & Thailand \\
\hline $\begin{array}{l}\text { Lammi- } \\
\text { Keefe CJ } \\
\text { et al., } 1990 \\
\text { [22] }\end{array}$ & US \\
\hline $\begin{array}{l}\text { Stafford J, } \\
1994 \text { [23] }\end{array}$ & Mexico \\
\hline
\end{tabular}

Weber A Germany

et al., 2001

[24]

Lubetzky R Israel

et al., 2006

[10]

Lubetzky R Israel

et al., 2007

[9]

Sanchez Spain
Lopez CL
et al., 2011
[25]

Khan S Australia

et al., 2013

[26]

Micro-Kjeldahl method (tota nitrogen) Crocker method (urea nitrogen) nitrogen, free amino acids (taurine, glutamine, glutamic acid)

25 (mothers of From the 1st Fat term infants) to 9 th months after delivery

6 (mothers of 8 weeks after Lipid, term infants) delivery

\section{carbohydrate,} protein, calories

Modified Folch procedure (lipid) YSI model 27 Industrial Analyser (lipid), micro- Kjeldahl method tion (calories)

Modified Folch method

Not specified Lipid

20 (mothers of The

The first 4 weeks of lactation 39 (mothers of 7-14 days preterm

infants, 26-33 weeks)

$$
\begin{array}{ll}
22 \text { (mothers of } & 2-7 \text { weeks } \\
\text { preterm } & \text { after delivery } \\
\text { infants, 26-31 } &
\end{array}
$$

weeks)

Total nitrogen and protein content

\section{Protein, fat}

Fat

Fat

CMT

Bicinchoninic acid method (protein), CMT (fat)

CMT

Kjeldahl method

Fat, lactose, total protein, casein, whey protein constant during the day; total lipid exhibited significant circadian variation, with peak concentration in the morning $(10.00 \mathrm{~h})$ and afternoon (14.00 h) samples (protein), Southgate-Durnin equaVLBW infants)

$\begin{array}{ll}69(11 & <2 \text { months } \\ \text { colostral } & \text { of lactation } \\ \text { group, } 27 & \\ \text { transitional } & \\ \text { group, } 31 & \\ \text { mature group) } & \\ 15 \text { (mothers of } & \text { From the 1st } \\ \text { term infants) } & \begin{array}{l}\text { to } 6 \text { th } \\ \text { months after } \\ \end{array} \\ & \begin{array}{l}\text { delivery }\end{array}\end{array}$
content
CMT (fat), enzymatic spectrophoto-metric method (lactose), Bradford protein assay (protein)
Concentrations of nitrogen significantly among women but were relatively constant during the day

Significant circadian variation, with maximum values between 16.00$20.00 \mathrm{~h}$ and minimum values between 04.00-08.00 h

Significant circadian variation of protein content, with maximum values at 6 AM and 6 PM. None of the other components varied significantly.

Significant circadian variations of volume and lipid yield were noted, peaking at 8.00-12.00 and 16.00$20.00 \mathrm{~h}$

Fat but not protein was lower in morning samples than in samples collected later in the day

CMT was significantly higher in evening (between $21.00 \mathrm{~h}$ and 24.00) than in morning (between $6.00 \mathrm{~h}$ and $9.00 \mathrm{~h}$ ) samples

Mean CMT was significantly higher in evening (9 PM to midnight) than morning samples (6-9 AM) during the first 7 weeks of lactation

In the group of mature lactating significantly higher during the night-time (20.00 h - $8.00 \mathrm{~h})$ than during the daytime (8.00-20.00 h)

Fat content significantly differed over $24 \mathrm{~h}$ (higher during the day and lower at night, with no difference between morning and evening); the concentration of substances in the milk differed women, protein content was 
Table 3 Summary of the studies on circadian changes in human milk macronutrient content (Continued)

\begin{tabular}{|c|c|c|c|c|c|c|}
\hline Reference & Site & $\begin{array}{l}\text { Participants } \\
\text { (number) }\end{array}$ & $\begin{array}{l}\text { Lactation } \\
\text { stage }\end{array}$ & $\begin{array}{l}\text { Macronutrients } \\
\text { investigated }\end{array}$ & Analytical methods & Results \\
\hline & & & & & & $\begin{array}{l}\text { lactose and protein remained the } \\
\text { same }\end{array}$ \\
\hline $\begin{array}{l}\text { Moran-Lev } \\
\text { H et al., } \\
2015 \text { [11] }\end{array}$ & Israel & $\begin{array}{l}32 \text { (mothers of } \\
\text { preterm } \\
\text { infants, 26-33 } \\
\text { weeks) }\end{array}$ & $\begin{array}{l}2-7 \text { weeks } \\
\text { after delivery }\end{array}$ & $\begin{array}{l}\text { Fat, } \\
\text { carbohydrate, } \\
\text { protein, energy }\end{array}$ & $\begin{array}{l}\text { Mid-infrared transmission } \\
\text { spectroscopy }\end{array}$ & $\begin{array}{l}\text { Fat and energy contents during } \\
\text { the whole period were } \\
\text { significantly higher in evening } \\
\text { samples; no significant differences } \\
\text { between morning and evening in } \\
\text { carbohydrates and protein } \\
\text { contents }\end{array}$ \\
\hline $\begin{array}{l}\text { Çetinkaya } \\
\text { AK et al., } \\
2017 \text { [27] }\end{array}$ & Turkey & $\begin{array}{l}52 \text { (mothers of } \\
30 \text { preterm } \\
\text { and } 22 \text { term } \\
\text { infants) }\end{array}$ & $\begin{array}{l}5-15 \text { lactation } \\
\text { days }(n=27) \\
\text { and }>15 \\
\text { lactation days } \\
(n=25)\end{array}$ & $\begin{array}{l}\text { Protein, fat, } \\
\text { carbohydrate }\end{array}$ & $\begin{array}{l}\text { Mid-infrared transmission } \\
\text { spectroscopy }\end{array}$ & $\begin{array}{l}\text { No significant difference was } \\
\text { found in the protein, fat, and } \\
\text { carbohydrate content of milk } \\
\text { samples throughout the day }\end{array}$ \\
\hline $\begin{array}{l}\text { Hollanders } \\
\text { JJ et al., } \\
2019 \text { [28] }\end{array}$ & Netherlands & $\begin{array}{l}10 \text { (mothers of } \\
\text { term infants) }\end{array}$ & $\begin{array}{l}1 \text { month after } \\
\text { delivery ( } \pm 5 \\
\text { days) }\end{array}$ & $\begin{array}{l}\text { Cortisol, } \\
\text { cortisone levels } \\
\text { and fat, } \\
\text { carbohydrate } \\
\text { and protein } \\
\text { content }\end{array}$ & $\begin{array}{l}\text { Mid-infrared transmission } \\
\text { spectroscopy }\end{array}$ & $\begin{array}{l}\text { While in all the mothers, a diurnal } \\
\text { rhythm of cortisol and cortisone } \\
\text { could be seen, no rhythm } \\
\text { appeared to be present for fat, } \\
\text { carbohydrates, and protein }\end{array}$ \\
\hline
\end{tabular}

US United States, VLBW very low birthweight, CMT creamatocrit

is another factor that may influence circadian fluctuations in human milk macronutrient content. It remains unclear, however, how these diurnal variations of human milk composition affect a newborn baby's growth pattern and own biorhythms.

\section{Strengths and limitations}

There are some limitations of our study.

Some of the women enrolled into the study could have preeclampsia and/or hypertension. Existing research shows that maternal preeclampsia or hypertension alters human milk composition [35-38], although there are very limited data on the influence of preeclampsia on human milk macronutrient content. Possible changes in human milk composition due to preeclampsia or hypertension may be a limitation of the generalizability of the study findings.

Analysis of the human milk macronutrient components was performed only during a short lactation period (i.e., 14-16 days after delivery), representing another limitation of our study. There are data showing that the circadian variation in human milk composition has different patterns throughout the evolution of the whole breastfeeding period $[25,39]$. Therefore, the results of our study can only be applied to the transitional phase of the lactation period and cannot be adjusted for other phases of lactation. On the other hand, the analysis of the circadian variations of the macronutrient content of human milk of the mothers of preterm and full-term newborns at the same time after delivery could be the strength of our study. To the best of our knowledge, no other study has tried to find diurnal differences in human milk macronutrient composition after preterm and term childbirths during the same lactation period.

We analyzed human milk samples for macronutrient content four times a day and divided the participants into two subgroups. Many statistical tests were undertaken. In addition to $p$ values, the effect sizes were calculated. The effect size should also be considered alongside estimation of the statistical significance: if the differences are significant (i.e., $p<0.05$ ), but the effect size is small, the differences between the groups may be considered unimportant. A further limitation of our study is the deployment of multiple comparisons, without correction for this. We also acknowledge that our findings may not be generalizable to other populations.

To avoid the influence of different associated factors on the content of macronutrients in expressed human milk, we tried to unify the sampling process as much as possible. We accepted only samples obtained after full expression of one or both breasts using the breast pump and excluded breastfeeding mothers. Analysis of fresh but not frozen human milk samples using a Miris analyser made our material homogenous and reliable for comparison.

\section{Conclusion}

Our study showed the circadian variability of human milk macronutrients, with the highest content of protein and fat during the day expressions (12 PM and 6 PM) and the lowest content during the night expressions $(12$ $\mathrm{AM}$ and $6 \mathrm{AM})$. There were no significant fluctuations in carbohydrate content in the human milk during $24 \mathrm{~h}$. Moreover, the circadian fluctuations of the 
macronutrient content in human milk were more prominent following premature childbirth. Further research is needed to clarify the circadian changes in maternal milk during the whole lactation period and to determine whether preterm babies could benefit from these changes in human milk composition.

\section{Acknowledgments}

We acknowledge the medical staff (L. Tamuliene, G. Zukiene, V. Mickeviciene) of the Human milk bank of the Neonatal Center of Vilnius University Hospital Santaros Klinikos for helping to obtain the milk samples and perform the Miris analysis. We also would like to thank the mothers who participated in the study.

\section{Authors' contributions}

IJP, $A L$ and $V U$ designed the study; $A L$ and $V U$ conducted the research; IJP was responsible for data collection, interpretation and wrote the first draft of the manuscript; $A \mathrm{~L}, \mathrm{AE}$ and $\mathrm{VU}$ contributed to the editing and preparation of the manuscript; AM assisted with statistical analysis and figures design. All authors read and approved the final manuscript.

\section{Funding}

This research received no external funding.

\section{Availability of data and materials}

The datasets used and analyzed during the current study are available from the corresponding author on reasonable request.

\section{Ethics approval and consent to participate}

The study was approved by the local bioethics committee (permission No. 158200-17-925-443). Before being enrolled in the study, all participating women provided written informed consent.

\section{Consent for publication}

Not applicable.

\section{Competing interests}

The authors declare no conflict of interest.

\section{Author details}

${ }^{1}$ Clinic of Children Diseases, Institute of Clinical Medicine, Faculty of Medicine, Vilnius University, Vilnius, Lithuania. ${ }^{2}$ Vilnius University Hospital Santaros Klinikos, Vilnius, Lithuania. ${ }^{3}$ Department of Human and Medical Genetics, Institute of Biomedical Sciences, Faculty of Medicine, Vilnius University, Vilnius, Lithuania. ${ }^{4}$ Department of Information Systems, Faculty of Fundamental Sciences, Vilnius Gediminas Technical University, Vilnius, Lithuania. ${ }^{5}$ State Research Institute, Center of Innovative Medicine, Department of Immunology, Vilnius, Lithuania.

\section{Received: 4 September 2019 Accepted: 11 May 2020}

Published online: 25 May 2020

\section{References}

1. Wu X, Jackson RT, Khan SA, Ahuja J, Pehrsson PR. Human milk nutrient composition in the United States: current knowledge, challenges, and research needs. Curr Dev Nutr. 2018;2(7):nzy025.

2. Gidrewicz DA, Fenton TR. A systematic review and meta-analysis of the nutrient content of preterm and term breast milk. BMC Pediatr. 2014;14:216.

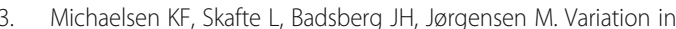
macronutrients in human bank milk: influencing factors and implications for human milk banking. J Pediatr Gastroenterol Nutr. 1990;11(2):229-39.

4. Garza C, Johnson CA, Harrist R, Nichols BL. Effects of methods of collection and storage on nutrients in human milk. Early Hum Dev. 1982;6(3):295-303.

5. Bauer J, Gerss J. Longitudinal analysis of macronutrients and minerals in human milk produced by mothers of preterm infants. Clin Nutr. 2011;30(2): 215-20.

6. Kreissl A, Zwiauer V, Repa A, Binder C, Thanhaeuser M, Jilma B, et al. Human Milk Analyser shows that the lactation period affects protein levels in preterm breastmilk. Acta Paediatr. 2016;105(6):635-40.
7. Czosnykowska-Łukacka M, Królak-Olejnik B, Orczyk-Pawiłowicz M. Breast milk macronutrient components in prolonged lactation. Nutrients. 2018;10(12): 1893.

8. Gunther M, Stanier JE. Diurnal variation in the fat content of breast-milk Lancet. 1949;2(6571):235-7.

9. Lubetzky R, Mimouni FB, Dollberg S, Salomon M, Mandel D. Consistent circadian variations in creamatocrit over the first 7 weeks of lactation: a longitudinal study. Breastfeed Med. 2007;2(1):15-8.

10. Lubetzky R, Littner Y, Mimouni FB, Dollberg S, Mandel D. Circadian variations in fat content of expressed breast milk from mothers of preterm infants. J Am Coll Nutr. 2006;25(2):151-4.

11. Moran-Lev H, Mimouni FB, Ovental A, Mangel L, Mandel D, Lubetzky R. Circadian macronutrients variations over the first 7 weeks of human milk feeding of preterm infants. Breastfeed Med. 2015;10(7):366-70.

12. White RD. Circadian variation of breast milk components and implications for care. Breastfeed Med. 2017;12(7):398-400.

13. Wagner $\mathrm{CL}$, Taylor $\mathrm{SN}$, Haase B. Designing longitudinal clinical studies involving lactating women. J Hum Lact. 2019;35(1):32-6.

14. Cederholm U, Hjort C, Ewald U, Nilsson D, Polberger S, Stigson L, et al. Guidelines for use of human milk and milk handling in Sweden. 2016; Available from: https://neo.barnlakarforeningen.se/wp-content/uploads/ sites/14/2014/03/Guidelines-2017-English.pdf. Accessed 21 Mar 2020.

15. Neville MC, Keller RP, Seacat J, Casey CE, Allen JC, Archer P. Studies on human lactation. I. Within-feed and between-breast variation in selected components of human milk. Am J Clin Nutr. 1984;40(3):635-46.

16. Lakens D. Calculating and reporting effect sizes to facilitate cumulative science: a practical primer for t-tests and ANOVAs. Front Psychol. 2013:4:863.

17. Prentice A, Prentice AM, Whitehead RG. Breast-milk fat concentrations of rural African women. 1. Short-term variations within individuals. $\mathrm{Br} J$ Nutr. 1981:45(3):483-94

18. Harzer G, Haug M, Dieterich I, Gentner PR. Changing patterns of human milk lipids in the course of the lactation and during the day. Am J Clin Nutr. 1983;37(4):612-21

19. Lavine ME, Clark RM, Hundrieser KE, Ferris AM. Within-day variation of lipolytic activity in human milk. J Dairy Sci. 1986;69(7):1784-6.

20. Clark RM, Ross SA, Hill DW, Ferris AM. Within-day variation of taurine and other nitrogen substances in human milk. J Dairy Sci. 1987;70(4):776-80.

21. Jackson DA, Imong SM, Silprasert A, Ruckphaopunt S, Woolridge MW, Baum JD, et al. Circadian variation in fat concentration of breast-milk in a rural northern Thai population. Br J Nutr. 1988;59(3):349-63.

22. Lammi-Keefe CJ, Ferris AM, Jensen RG. Changes in human milk at 0600, 1000, 1400, 1800, and 2200 h. J Pediatr Gastroenterol Nutr. 1990;11(1):83-8.

23. Stafford J, Villalpando S, Urquieta AB. Circadian variation and changes after a meal in volume and lipid production of human milk from rural Mexican women. Ann Nutr Metab. 1994:38(4):232-7.

24. Weber A, Loui A, Jochum F, Bührer C, Obladen M. Breast milk from mothers of very low birthweight infants: variability in fat and protein content. Acta Paediatr. 2001;90(7):772-5.

25. Sánchez López CL, Hernández A, Rodríguez AB, Rivero M, Barriga C, Cubero J. Análisis del contenido en nitrógeno y proteínas de leche materna, día vs noche [nitrogen and protein content analysis of human milk, diurnality vs nocturnality]. Nutr Hosp. 2011;26(3):511-4.

26. Khan S, Hepworth AR, Prime DK, Lai CT, Trengove NJ, Hartmann PE. Variation in fat, lactose, and protein composition in breast milk over 24 hours: associations with infant feeding patterns. J Hum Lact. 2013:29(1):81-9.

27. Çetinkaya AK, Dizdar EA, Yarcı E, Sari FN, Oguz SS, Uras N, et al. Does circadian variation of mothers affect macronutrients of breast milk? Am J Perinatol. 2017;34(7):693-6.

28. Hollanders JJ, Kouwenhoven SMP, van der Voorn B, van Goudoever JB, Rotteveel J, Finken MJJ. The association between breastmilk glucocorticoid concentrations and macronutrient contents throughout the day. Nutrients. 2019:11(2):259.

29. Nommsen LA, Lovelady CA, Heinig MJ, Lönnerdal B, Dewey KG. Determinants of energy, protein, lipid, and lactose concentrations in human milk during the first 12 mo of lactation: the DARLING study. Am J Clin Nutr. 1991:53(2):457-65.

30. Daly SE, Di Rosso A, Owens RA, Hartmann PE. Degree of breast emptying explains changes in the fat content, but not fatty acid composition, of human milk. Exp Physiol. 1993;78(6):741-55.

31. Silvestre D, Fraga M, Gormaz M, Torres E, Vento M. Comparison of midinfrared transmission spectroscopy with biochemical methods for the 
determination of macronutrients in human milk. Matern Child Nutr. 2014; 10(3):373-82.

32. Zhu M, Yang Z, Ren Y, Duan Y, Gao H, Liu B, et al. Comparison of macronutrient contents in human milk measured using mid-infrared human milk analyser in a field study vs. chemical reference methods. Matern Child Nutr. 2017;13(1):e12248.

33. Casadio YS, Williams TM, Lai CT, Olsson SE, Hepworth AR, Hartmann PE. Evaluation of a mid-infrared analyzer for the determination of the macronutrient composition of human milk. J Hum Lact. 2010;26(4):376-83.

34. Fusch G, Rochow N, Choi A, Fusch S, Poeschl S, Ubah AO, et al. Rapid measurement of macronutrients in breast milk: how reliable are infrared milk analyzers? Clin Nutr. 2015;34(3):465-76.

35. Dangat K, Kilari A, Mehendale S, Lalwani S, Joshi S. Preeclampsia alters milk neurotrophins and long chain polyunsaturated fatty acids. Int J Dev Neurosci. 2014;33:115-21.

36. Dangat K, Upadhyay D, Kilari A, Sharma U, Kemse N, Mehendale S, et al. Altered breast milk components in preeclampsia; an in-vitro proton NMR spectroscopy study. Clin Chim Acta. 2016;463:75-83.

37. Amaral YN, Rocha DM, Silva LM, Soares FVM, Moreira MEL. Do maternal morbidities change the nutritional composition of human milk? A systematic review. Cien Saude Colet. 2019;24(7):2491-8.

38. Massmann PF, França EL, de Souza EG, Souza MS, Brune MFSS, HonorioFrança AC. Maternal hypertension induces alterations in immunological factors of colostrum and human milk. Front Life Sci. 2013;7(3-4):155-63.

39. Sánchez CL, Cubero J, Sánchez J, Franco L, Rodríguez AB, Rivero M, et al. Evolution of the circadian profile of human milk amino acids during breastfeeding. J Appl Biomed. 2013;11(2):59-70.

\section{Publisher's Note}

Springer Nature remains neutral with regard to jurisdictional claims in published maps and institutional affiliations.

Ready to submit your research? Choose BMC and benefit from:

- fast, convenient online submission

- thorough peer review by experienced researchers in your field

- rapid publication on acceptance

- support for research data, including large and complex data types

- gold Open Access which fosters wider collaboration and increased citations

- maximum visibility for your research: over $100 \mathrm{M}$ website views per year

At $\mathrm{BMC}$, research is always in progress.

Learn more biomedcentral.com/submissions 